Jurnal Analis Medika Bio Sains

Vol.5, No.2, September 2018, pp. 114 124

ISSN: 2656-2456 (Online)

ISSN: 2356-4075 (Print)

\title{
KANDUNGAN TEH BAYAM MERAH (AMARANTHUS TRICOLOR L) DAN TOKSISITAS AKUT PADA TIKUS PUTIH STRAIN WISTAR
}

\author{
Pancawati Ariami ${ }^{1}$, Farida $^{2}$, Jubair ${ }^{3}$ \\ ${ }^{1-2}$ Jurusan Analis Kesehatan, Poltekkes Kemenkes Mataram, Indonesia \\ ${ }_{3}^{3}$ Jurusan Keperawatan, Poltekkes Kemenkes Mataram, Indonesia
}

\begin{tabular}{l} 
Article Info \\
\hline Article history: \\
Received Jul $17^{\text {th }}, 2018$ \\
Revised Aug $24^{\text {th }}, 2018$ \\
Accepted Sept $19^{\text {th }}, 2018$ \\
\hline
\end{tabular}

Keyword:

Acute toxicity,

Red spinach tea content

\begin{abstract}
Tea in everyday life is a soft drink as an introduction to enjoying light dishes with distinctive flavors. Red spinach has been studied as an antitumor / anticancer, and in the form of tea preparations. Laboratory research which is a true-experimental study with a pretest-posttest design accompanied by controls. Red spinach tea content was identified by the GC-MS method, and spectrophotometric and gravimetric levels were determined. The acute toxicity test of red spinach tea was adjusted to the in vivo Nonclinical Toxicity Test Guideline of the Food and Drug Administration, number 7 of 2014, where the acute toxicity test used a fixed dose method method for groups of male Wistar rats and groups of female white rats fed spinach red with doses of 50, 300, 2000, and $5000 \mathrm{mg} / \mathrm{kg} \mathrm{BB}$. The main compounds resulting from identification using GCMS are palmitic acid, elaidin acid / oleic acid, phytol, and stearic acid. Determination of the total phenol equivalent level of gallic acid in fresh red spinach tea $4.11 \% \mathrm{~b} / \mathrm{b}$ and in stored tea decreased to $1.78 \% \mathrm{~b} / \mathrm{b}$. Determination of total levels of flavonoids equivalent to quercetin in fresh red spinach tea was $0.98 \% \mathrm{~b} / \mathrm{b}$ and decreased to $0.435 \% \mathrm{~b} / \mathrm{b}$ after storage. Water content and water soluble extract levels in the new tea preparations were $20.47 \%$ and $15.18 \% \mathrm{~b} / \mathrm{b}$ while those in the stored tea increased to $24.83 \%$ and $18.41 \% \mathrm{~b} / \mathrm{b}$. Acute toxicity test stated that red spinach tea is not toxic.
\end{abstract}

\begin{abstract}
ABSTRAK
Teh dalam kehidupan sehari-hari merupakan minuman ringan sebagai pengantar dalam menikmati hidangan ringan dengan cita rasa yang khas. Bayam merah telah diteliti sebagai antitumor/antikanker, dan dalam bentuk sediaan teh. Penelitian laboratorium yang merupakan penelitian true-experimental dengan desain pretest-posttest disertai kontrol. Kandungan teh bayam merah diidentifikasi dengan metode GC-MS, dan penetapan kadar secara spektrofotometri dan gravimetri. Uji toksisitas akut teh bayam merah disesuaikan dengan Pedoman uji toksisitas nonklinik in vivo dari Badan Pengawas Obat dan Makanan, nomor 7 tahun 2014, kelompok tikus putih Wistar jantan dan kelompok tikus putih betina yang diberi teh bayam merah dengan dosis 50, 300, 2000, dan $5000 \mathrm{mg} / \mathrm{kg}$ BB. Senyawa utama yang dihasilkan dari identifikasi menggunakan GCMS adalah asam palmitat, asam elaidin/asam oleat, phytol, dan asam stearat. Penetapan kadar total phenol ekuivalen asam gallat pada teh bayam merah segar $4,11 \% \mathrm{~b} / \mathrm{b}$ dan pada teh yang disimpan turun menjadi $1,78 \% \mathrm{~b} / \mathrm{b}$. Penetapan kadar total flavonoid ekuivalen quercetin pada teh bayam merah segar $0,98 \%$ b/b dan menurun menjadi $0,435 \%$ b/b setelah disimpan. Kadar air dan kadar sari larut air pada sediaan teh yang baru $20,47 \%$ dan $15,18 \%$ b/b sedangkan pada teh yang telah disimpan meningkat menjadi $24,83 \%$ dan $18,41 \%$ b/b. Uji toksisitas akut dinyatakan bahwa teh bayam merah tidak toksis.
\end{abstract}

Kata kunci : kandungan teh bayam merah, toksisitas akut 


\section{Pendahuluan}

Pengendalian pertumbuhan dan pembelahan sel ganas dengan pemberian obat sitostatika, berperan sebagai zat anti mitosis atau antineoplastik. Namun pemberian obat anti mitosis dalam jangka waktu panjang menimbulkan efek samping, seperti menekan fungsi sumsum tulang, gangguan menstruasi, mual-mual, muntah dan sakit kepala. Zat anti mitosis dapat memperbaiki kerusakan atau gangguan pembelahan sel secara teori mengandung zat antioksidan (Jong, 2005). Kandungan zat-zat antioksidan telah terbukti dapat dimanfaatkan sebagai zat anti kanker (anti mitosis). Salah satu tanaman yang banyak mengandung antioksidan adalah bayam merah (Jong, 2005 ; Astawan, 2004).

Bayam merah (Amaranthus trocolor L) telah lama dikenal oleh masyarakat Indonesia. Bayam merah merupakan bahan sayuran yang bergizi tinggi dan digemari oleh semua lapisan masyarakat. Bayam merah juga salah satu sayuran dengan sumber protein, vitamin A dan C serta sedikit vitamin B dan mengandung garam-garam mineral seperti kalsium, pospor, dan zat besi (Sunarjono, 2006).

Daun bayam merah (Amaranthus tricolor L) juga mempunyai potensi sebagai anti diuretika. Kandungan senyawa kimia pada bayam merah meliputi amaranthi, kalium nitrat, besi, piridoksin juga mengandung vitamin $\mathrm{A}, \mathrm{C}$ dan $\mathrm{K}$ juga ditemukan garam fosfat. Daun maupun akar bayam merah digunakan orang sebagai pelancar ASI, peluruh air seni ada juga yang menggunakan sebagai penambah darah, Masyarakat memanfaatkan bayam merah dengan cara meminum air seduhan daun atau akar bayam merah. Pemberian ekstrak daun bayam merah sebanyak 25\% dapat meningkatkan produksi urine sebanyak 2 kali lipat dibanding tikus tanpa pemberian daun bayam merah (Trihardjana, 2007)

Berdasarkan Jurnal Anti cancer potential of flavonoids menunjukan kandungan senyawa flavonoid sebagai antioksidan yang terkandung pada daun bayam merah berperan menurunkan resiko kanker termasuk sebagai pencegahan kanker (kemoterapi) dengan memilah berbagai bagian faktor, regulasi dan mekanisme molekuler bersama dengan interaksi protein yang signifikan. Mekanisme molekuler flavonoid sebagai anti kanker mampu menghambat fosforilasi protein, menghambat enzim prooksidan, mengatur katabolisme karsinogen, menghambat resintensi obat, memberikan efek antioksidan dalam menangkal radikal bebas, menghambat pembentukan pembuluh darah pada jaringan kanker (anti angiogenesis), menyebabkan apoptosis dan menahan peredaran sel (cycle arrest). (Batra \& Sharma, 2013).

Penelitian mengenai pengaruh pemberian bayam merah terhadap aktivitas zat anti mitosis menggunakan hewan coba bulu babi. Pemodelan linier pada tahap pembelahan sel secara binair dari satu sel, menjadi dua sel, empat sel dan seterusnya menjadi $2^{\wedge} \mathrm{n}$, yang berlangsung cepat seperti sel kanker sehingga mudah diamati (Sukardja, 2000). Peran bayam merah dalam bentuk teh sebagai zat anti mitosis telah diuji pada bulu babi pada konsentrasi yang 0,1\% sampai jam ke-4 hanya mampu berada pada tahap zigot dan tidak dapat berubah menjadi 2 sel. (Ariami, Adiadnya \& Diarti, 2015).

Laporan ilmiah khasiat daun' bayam merah, terutama dalam bentuk sediaan teh belum banyak dilaporkan. Daun bayam merah dalam bentuk sediaan teh sangat mudah dibuat dan disajikan. Teh merupakan minuman ringan yang sering dikonsumsi sebagai pengantar dalam menikmati hidangan ringan dan mempunyai rasa yang tidak menyolok seperti obat yang rata-rata pahit dibandingkan herbalherbal lain yang digunakan sebagai obat tradisional.

Teh bayam merah yang akan digunakan sebagai obat herbal terstandar yang akan diedarkan di pasaran harus melewati uji keamanan menggunakan hewan coba sebagai model dalam bentuk uji toksisitas nonklinik, yang dilakukan invivo, meliputi: uji toksisitas akut oral, toksisitas subkronis oral, toksisitas kronis oral, teratogenisitas, sensitisasi kulit, iritasi mata, iritasi akut dermal, iritasi mukosa vagina, toksisitas akut dermal, dan toksisitas subkronis dermal. Pemilihan uji tersebut, tergantung dari tujuan penggunaan suatu zat dan kemungkinan terjadinya risiko akibat pemaparan pada manusia (Peraturan Kepala BPOM RI, 2014).

Keabsahan uji toksisitas sangat dipengaruhi beberapa faktor yaitu sediaan uji, penyiapan sediaan uji, hewan uji, dosis, teknik dan prosedur pengujian, serta kemampuan SDM sehingga sangat diperlukan pemahaman terhadap bermacam-macam faktor tersebut. Agar keabsahan hasil uji toksisitas dapat terjamin dan diterima secara nasional dan internasional, maka digunakan pedoman uji toksisitas yang sudah baku. (Peraturan Kepala BPOM RI, 2014). 
Hasil uji sebagai zat antimitosis, bentuk penyajian yang mudah, dengan penelitian "Model sel tumor hepar mencit Balb/C pada pemberian teh bayam merah (Amaranthus tricolor L)" didapat bahwa perbaikan sel sinosoid dengan pemberian teh bayam merah 1\%, akan tetapi memburuk pada konsentrasi yang lebih tinggi; Oedema sel makin berkurang seiring dengan meningkatnya konsentrasi teh bayam merah; Nekrosis sel hepar mencit mengalami perbaikan hingga dibawah $10 \%$ terjadi pada pemberian teh bayam merah 1\%; Konsentrasi yang tinggi dari teh bayam merah (di atas 1\%), tidak dapat memberi efek perbaikan sel, akan tetapi sebaliknya dapat bersifat toksik dan menyebabkan nekrosis sel hepar mencit makin luas; Hasil pengamatan mikroskopis menunjukkan respon perbaikan sel hepar mencit Balb/C jantan yang diinduksi dengan benzo[a]pyrene, terbaik adalah dengan pemberian teh bayam merah konsentrasi $1 \%$. Hasil penelitian di atas mendorong kami ingin melakukan penelitian lanjutan untuk mengetahui "Kandungan dan Toksisitas teh bayam merah (Amaranthus tricolor L) dan pengaruhnya terhadap perbaikan sel hepar tikus putih strain Wistar yang dipapar Benzo[a]pyrene.” Bayam merah telah diketahui kandungan bahan kimianya, namun apakah dalam bentuk sediaan teh masih mempunyai kandungan yang sama belum diketahui. Hal ini merupakan salah satu informasi yang diperlukan sebelum melakukan uji toksisitas.

\section{Metode Penelitian}

Penelitian ini merupakan penelitian true-experiment yang menguraikan tentang identifikasi dan pengujian kandungan bahan aktif teh bayam merah (Amaranthus tricolor L) dan uji toksisitas akut terhadap tikus putih strain Wistar. Teh bayam merah dibuat dari bayam merah dari jenis Amaranthus tricolor $L$ yang sudah layak panen. Bayam merah diambil secara random pada varietas tanaman yang sama hingga memenuhi kebutuhan, yaitu daun dan batang bayam merah yang diambil sepanjang $\pm 15 \mathrm{~cm}$ dari pucuk.

Jumlah unit eksperimen uji toksisitas dan pengaruh pemberian teh bayam merah pada sel tumor hepar tikus putih pada penelitian ini dilakukan menurut Peraturan Kepala BPOM RI nomor 7 tahun 2014. Untuk uji toksisitas akut oral dalam penelitian ini digunakan 30 ekor tikus putih dari strain Wistar dengan jenis kelamin jantan berumur 12-14 minggu, yaitu 4 perlakuan dan 1 kelompok kontrol yang masingmasing terdiri dari 3 ekor tikus jantan dan 3 ekor tikus betina. Data yang diperoleh dari hasil pengamatan berupa penghambatan pertumbuhan sel tumor hepar tikus putih (Rattus norvegicus) strain Wistar yang diberi teh bayam merah dikumpulkan secara deskriptif.

\section{Hasil Penelitian}

\section{Penentuan jenis bayam merah untuk dibuat teh}

Telah dilakukan identifikasi/determinasi bayam merah di laboratorium Biologi $\quad$ F-MIPA Unram dan dinyatakan bahwa nama ilmiah/latin specimen adalah Amaranthus tricolor $L$.

2. Pembuatan teh bayam merah dari bayam merah.

Bayam merah disiangi, ditimbang, baru dicuci untuk menghlangkan sisa-sisa kotoran, tanah, dan debu yang melekat. Pembuatan teh bayam merah telah dilakukan beberapa kali dengan perbandingan berat basah dan kering dapat dilihat pada tabel berikut:

Tabel 1. Hasil pembuatan teh bayam merah

\begin{tabular}{lllll}
\hline No & Tanggal buat & Berat basah $(\mathrm{g})$ & Tanggal selesai & Berat kering $(\mathrm{g})$ \\
\hline 1 & 4 Agustus & 1927 & 8 Agustus & 276 \\
2 & 12 Agustus & 765 & 15 Agustus & 127 \\
3 & 23 Oktober & 1048 & 25 Oktober & 142 \\
\hline
\end{tabular}

Persentase hasil pengeringan bayam merah menjadi teh berturut-turut 14,32\%; 16,60\%; dan 13,55.

\section{Identifikasi kandungan bahan aktif/kimia teh bayam merah dengan menggunakan} Kromatografi Gas-Spekrofotometri Massa 
Identifikasi teh bayam merah didahului dengan mengeringkan teh bayam merah sampai benar-benar kering dengan cara kering-angin untuk meminimalkan kadar air sehingga memudahkan proses menggunakan GC. Sampel diblender halus, kemudian dimaserasi selama 24 jam menggunakan ethanol absolut. Sari hasil penyaringan diidentifikasi menggunakan GCMS dengan hasil sbb:

Sampel A1-F adalah sampel teh bayam merah yang baru jadi, ditemukan 5 senyawa yang menonjol keberadaannya, yaitu peak 10, 8, 11, 12, dan 4 berturut-turut:

a. Peak 4: Rumus bangun C20 H38, dengan nama Neophytadiene = 2,6,10-trymethyl, 14ethylene-14-pentadecne.

b. Peak 8: Rumus bangun $\mathrm{C} 16 \mathrm{H} 32 \mathrm{O} 2$, dengan nama Hexadecanoic acid (CAS) Palmitic acid = Palmitinic acid $=\mathrm{n}$-Hexadecanoic acid $=$ coconut oil fatty acid $=$ Hystrene $=$ Emersol $=$ Palmitinsaeure

c. Peac 10: Rumus bangun C20 H40 O, dengan nama 2-hexadecen-1-ol, 3,7,11,15,-tetramethyl, [R[R',R'-E)]]-CAS Phytol.

d. Peak 11: Rumus bangun C18 H34 O2, dengan nama Heptadecene-(8)-carbonic acid-(1)

e. Peak 12: Rumus bangun C18 H36 O2, dengan nama Octadecanoic acid (CAS) Stearic acid

Adapun kromatogram yang diperoleh seperti yang diperlihatkan pada Gambar 1.

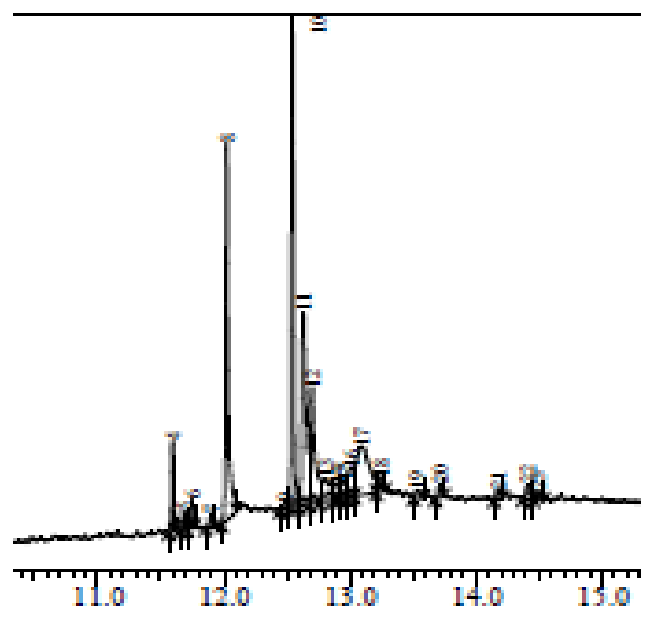

Gambar 1. Kromatogram hasil GCMS dari teh bayam merah yang baru jadi

Sampel A2-2b adalah sampel teh bayam merah yang telah disimpan selama 2 bulan dan dilakukan pemeriksaan dengan metode yang sama, diperoleh berturut-turut dari peak tertinggi dimulai peak 9,6,8,24,10,21 adalah seperti pada Gambar 2

a. Peak 6: Rumus bangun C16 H32 O2, dengan nama Hexadecanoic acid (CAS) Palmitic acid ( sama dengan peak 8 pada pengujian I)

b. Peak 8: Rumus bangun C20 H40 O, dengan nama 2-hexadecen-1-ol, 3,7,11,15,-tetramethyl, [R[R',R'-E)]]-CAS Phytol (sama dengan peak 10 pada pengujian I)

c. Peak 9: Rumus bangun $\mathrm{C} 18 \mathrm{H} 34 \mathrm{O} 2$, dengan nama octadec-9-enoic = elaidinsaeure.

d. Peak 10: Rumus bangun C18 H36 O2, dengan nama Octadecanoic acid (CAS) Stearic acid (sama dengan peak 12 pada pengujian I)

e. Peak 21: Rumus bangun C19 H38 O0, dengan nama Hexadecanoic acid, 2-hidroxy1(hydroxymethyl)ethyl ester (CAS) 2-Monopalmitin

f. Peak 24: Rumus bangun C21 H40 O4, dengan nama 9-Octadecanoic acid (Z), -hydroxy-1(hydroxymethyl) ethyl ester (CAS) 2-Monoolein 


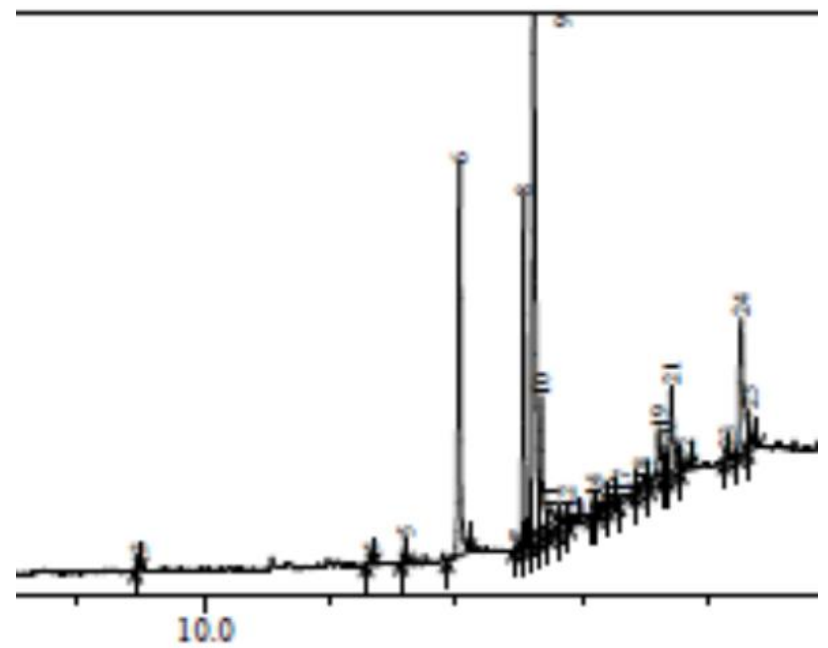

Gambar 2. Kromatogram hasil pemeriksaan GCMS pada teh bayam merah yang telah disimpan selama 2 bulan

\section{Menentukan kadar bahan aktif dalam teh bayam merah}

Kadar bahan aktif yang diuji di LPPT-UGM dengan parameter Total fenol ekuivalen Asam Gallat, Total Flavonoid Ekuivalen Quercetin, Kadar Air dan Kadar sari larut air. Adapun hasil uji dapat diamati pada tabel dibawah ini:

Tabel 2. Hasil penetapan kadar bahan aktif sediaan teh bayam merah

\begin{tabular}{llllll}
\hline No & Parameter Uji (satuan) & $\begin{array}{l}\text { Bayam } \\
\text { segar }\end{array}$ & $\begin{array}{l}\text { merah } \\
\text { baru bayam merah }\end{array}$ & $\begin{array}{l}\text { Teh bayam merah } \\
\text { simpan (2 bulan) }\end{array}$ \\
\hline 1 & $\begin{array}{l}\text { Total fenol ekuivalen Asam } \\
\text { Gallat (\% b/b) }\end{array}$ & 1,81 & 4,11 & 1,78 \\
2 & Total Flavonoid Ekuivalen & 0,22 & 0,98 & 0,435 \\
& $\begin{array}{l}\text { Quercetin }(\% \text { b/b) } \\
3\end{array}$ & Kadar air (\%) & & \\
4 & Kadar sari larut air (\% b/b) & 4,19 & 20,47 & 24,83 \\
\hline
\end{tabular}

\section{Menentukan toksisitas akut oral dari teh bayam merah}

Hasil uji toksisitas akut oral terhadap sekolompok tikus putih dengan dosis $50 \mathrm{mg} / \mathrm{kg} \mathrm{BB}, 300 \mathrm{mg} / \mathrm{kg} \mathrm{BB}$, $2000 \mathrm{mg} / \mathrm{kg} \mathrm{BB}$, dan $5000 \mathrm{mg} / \mathrm{kg} \mathrm{BB}$.

Teh bayam merah ditimbang 37,5 gram, dimasak dalam $500 \mathrm{ml}$ air mendidih selama 1 menit. Api dimatikan dan teh dimasukkan, diaduk, dan dibiarkan mendidih satu kali berbunga. Api dimatikan, dibiarkan dingin, saring, dan peras. Pemberian teh bayam merah untuk uji toksisitas akut oral (fixed dose method) dengan cara disonde dengan volume pemberian seperti pada tabel dengan jarak pemberian tidak lebih dari 3 jam. Pemberian sediaan pada setiap hewan coba dilakukan 1 sampai dengan 3 kali tergantung dosis

Uji toksisitas dilakukan selama 24 jam pertama, hewan coba diamati setiap jam. Pengamatan terhadap hewan coba dilakukan setiap hari sampai hari ke-14. Hasil uji toksisitas dinyatakan hewan uji setelah 14 hari masih dalam keadaan sehat dan aktif. Penentuan kategori toksisitas akut diberikan sampai dosis $5000 \mathrm{mg} / \mathrm{kg}$ BB dengan klasifikasi sebagai toksik ringan, diperoleh semua tikus hidup baik jenis kelamin jantan maupun tikus betina, sehat, tidak ditemukan penurunan aktivitas tikus, yang berarti dapat memasuki klasifikasi praktis tidak toksik. Batas Uji sesuai dengan Pedoman uji toksisitas non klinik secara in vivo dinyatakan bila hingga dosis $5000 \mathrm{mg} / \mathrm{kg}$ BB (pada tikus) tidak menimbulkan kematian, maka uji tidak perlu dilanjutkan dengan menggunakan dosis bahan uji yang lebih tinggi. 


\section{Pembahasan}

Pada proses pembuatan teh bayam merah dari bayam merah terjadi susut pengeringan sebanyak 20 sampai $24 \%$ pada dua berapa kali proses pembuatan. Hal ini tergambar dari perbedaan kadar air dari teh bayam merah yang dihasilkan Antosianin adalah senyawa fenolik yang masuk kelompok flavonoid yang berfungsi sebagai antioksidan. Purnawijayanti (2009), menyebutkan bahwa bayam mengandung karotenoid dan flavonoid yang merupakan zat aktif dengan khasiat sebagai antioksidan. Menurut Akhda (2009), kandungan pigmen antosianin pada tanaman dipengaruhi oleh intensitas cahaya matahari, suhu udara, dan $\mathrm{pH}$. Kandungan antosianin pada musim kemarau lebih tinggi.

Sedangkan Herani dan Rahardjo (2005), menyebutkan bahwa warna merah, biru, dan ungu pada buah, daun, dan bunga suatu tanaman dipengaruhi oleh pigmen antosianin. Susanti (2012) dalam Pebrianti, Ainurrasyid, \& Purnamaningsih (2015), antosianin pada tanaman berfungsi sebagai pelindung terhadap UV B dan melindungi kloroplas terhadap intensitas cahaya tinggi. Antosianin juga berperan sebagai sarana transport monosakarida dan pengatur osmotic selama periode kekeringan dan suhu rendah. Antosianin meningkatkan respon antioksidan tanaman untuk pertahanan hidup pada stress biotik dan abiotik. Kandungan antosianin yang tinggi ditemukan pada bayam merah yang memiliki warna merah daun yang lebih gelap.

Beberapa faktor yang mempengaruhi stabilitas antara lain, yang pertama $\mathrm{pH}$. Warna yang ditimbulkan oleh antosianin tergantung dari tingkat keasaman $(\mathrm{pH})$ lingkungan sekitar sehingga pigmen ini dapat dijadikan sebagai indikator $\mathrm{pH}$. Warna yang ditimbulkan adalah merah $(\mathrm{pH} \mathrm{1)}$, biru kemerahan $(\mathrm{pH} 4)$, ungu ( $\mathrm{pH} 6)$,

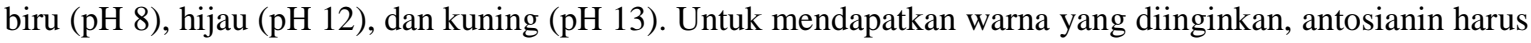
disimpan menggunakan larutan bufer dengan $\mathrm{pH}$ yang sesuai. Kedua Kation. Sebagian kation, terutama kation divalen dan trivalen harus dihindari karena dapat menyebabkan perubahan warna antosianin menjadi biru hingga terjadi pengendapan pigmen. Selain itu, permukaan tembaga, baja ringan, dan besi juga sebaiknya dihindari. Ketiga adalah Oksigen. Saat terlarut di dalam suatu larutan campuran, antosianin akan teroksidasi perlahan-lahan. Ke-empat Sulfur dioksida (SO2). Apabila sulfur dioksida bereaksi dengan antosianin maka akan terbentuk produk yang tidak berwarna.

Reaksi perubahan warna tersebut bersifat reversible sehingga hanya dengan memanaskan SO2 maka warna akan kembali seperti semula. Ke-lima Protein. Apabila sumber antosianin bereaksi dengan protein maka akan terbentuk uap atau endapan. Peristiwa ini lebih dipengaruhi oleh pigmen non fenolik yang bereaksi dengan protein seperti gelatin. Ke-enam adalah Enzim. Penggunaan beberapa enzim dalam pengolahan makanan yang mengandung antosianin dapat mengakibatkan kandungan antosianin di dalamnya hilang atau berkurang. Hal ini sebagian disebabkan oleh enzim glukosidase yang ada pada tahap preparasi enzim. (Houghton \& Hendry, 1995).

Amaranthus tricolor berasal dari daerah Amerika tropis dan disebut tricolor karena daunnya berwarna 3 yaitu hijau, merah dan keunguan. Kandungan seratnya yang tinggi sangat bagus untuk pencernaan dan juga merupakan sumber zat warna alami karotenoid. Karotenoid adalah pewarna alami yang larut dalam lemak, metabolit sekunder dari jenis terpenoid berupa suatu poliisoprenoid panjang (terdiri atas 40 atom karbon/tetraterpen). Karotenoid dapat ditemukan dalam tumbuhan, beberapa jenis hewan, alga, bakteri dan jamur. Pigmen karotenoid pada tumbuhan mempunyai dua fungsi, yaitu sebagai pigmen pembantu dalam fotosintesis dan sebagai pewarna dalam bunga dan buah. Karotenoid merupakan pigmen yang berwarna kuning, oranye atau merah, sehingga dapat diidentifikasi melalui warnanya. Penelitian sebelumnya (di China) terhadap Amaranthus tricolor telah ditemukan senyawa zat warna lutein (sebagai komponen utamanya), zeasantin, violasantin, neosantin, $\beta$-karoten.7 Tumbuhan yang sama dari Malaysia menghasilkan senyawa karotenoid jenis $\beta$-karoten dan lutein. Isolasi senyawa karotenoid dari bayam merah (Amaranhus tricolor L) menghasilkan isolat murni berwujud pasta berwarna orange kemerahan (Sulistyaningrum, 2014).

Pada penelitian dengan mengisolasi teh bayam merah menggunakan ethanol absolut menghasilkan pasta berwarna hijau dengan hasil dari teh bayam merah yang baru dibuat senyawa yang sering dikenal adalah asam palmitat (histrene, coconut oil fatty acid) yang berada pada peak kedua tertinggi. Sedangkan pada sediaan teh bayammerhyang telah disimpan selama 2 bulan, hasil identifikasi menggunakan GCMS dengan kandungan asam palmitat yang juga berada pada peak kedua tertinggi yang sama-sama muncul pada menit ke-12, namun dalam \%-area dan \%-tinggi yang lebih rendah dibandingkan dengan pengujian pada teh bayam merah baru. 
Elaidinsaeure, Asam samarat (dari gr. Elaion, "minyak") adalah asam lemak tak jenuh tunggal. Molekul tersebut mengandung rantai 18 atom karbon yang tidak bercabang dengan ikatan rangkap tunggal di tengahnya. Karena kedua bagian rantai berada dalam pengaturan trans pada ikatan rangkap, juga digunakan asam lemak trans. Rumus kimianya adalah $\mathrm{CH} 3-(\mathrm{CH} 2)$ 7-CH $=\mathrm{CH}-(\mathrm{CH} 2)$ 7-COOH, asam trans-9octadecenoic yang sistematis. Isomer cis yang sesuai, yang jauh lebih melimpah di alam, disebut asam oleat. Asam elaidik membentuk kristal tak berwarna dengan densitas $0,87 \mathrm{~kg} / 1$ yang meleleh pada 44 sampai $45^{\circ}$ C. Lemak (triester gliserin) dengan residu asam elayat dapat tidak diinginkan timbul dalam pengerasan lemak, proporsi gliserida yang lebih kecil juga ditemukan pada lemak susu, lemak sapi dan lemak lainnya dari ruminansia. Deteksi dan pengujian asam elayat biasanya dilakukan dengan kromatografi gas metil ester; Selain itu, pemisahan isomer tak jenuh dapat dilakukan dengan kromatografi lapis tipis perak nitrat (Wikipedia, 2017).

Asam palmitat (asam heksadekanoat) adalah asam organik jenuh dan dihitung di antara asam lemak (= asam karboksilat yang lebih tinggi). Palmitat (secara sistematis juga heksadekanoat) adalah garam dan ester asam palmitat. Asam palmitat adalah padatan tak berwarna pada suhu kamar. Palmitate adalah zat antara utama dalam metabolisme banyak makhluk, dari mana semua asam lemak lainnya dibuat untuk membangun toko lemak dalam bentuk gliserida. Biosintesis palmitat terjadi dalam lipogenesis prekursor molekul kecil dalam proses berulang dimana dua molekul karbon terikat pada rantai molekul dengan setiap langkahnya. Nama palmitic berasal dari isolasi minyak sawit oleh Edmond Frémy (tahun 1840).

Pulp dari kelapa sawit menyediakan minyak kelapa sawit yang trigliserida kaya akan residu asam palmitat. Residu asam palmitat adalah residu asam lemak jenuh yang paling sering terjadi pada banyak lemak nabati dan hewan dan minyak lemak sebagai gliserol ester. Penentuan asam palmitat kualitatif dan kuantitatif yang andal dalam berbagai bahan uji berhasil setelah preparasi dan transesterifikasi sampel yang memadai menjadi metil ester dengan menggabungkan kromatografi gas kapiler dengan spektrometri massa. Palmitat biasanya digunakan dalam kosmetik. (Wikipedia, 2017).

Phytol adalah alkohol siklipik asiklik dan penyusun klorofil. Fitol umumnya digunakan sebagai prekursor untuk pembuatan bentuk sintetis vitamin E dan vitamin K1. Selanjutnya, fitol juga ditunjukkan untuk memodulasi transkripsi dalam sel melalui faktor transkripsi PPAR-alpha dan reseptor retinoid X (RXR). Fitol adalah alkohol diterpene linier alami yang digunakan dalam pembuatan vitamin $\mathrm{E}$ dan $\mathrm{K} 1$. Ini juga merupakan produk dekomposisi klorofil. Ini adalah cairan berminyak yang hampir tidak larut dalam air, namun bisa larut di sebagian pelarut organik (NCBI, 2017).

Phytol adalah alkohol acyclic diterpene yang dapat digunakan sebagai prekursor untuk pembuatan bentuk sintetis vitamin E dan vitamin K1. Dalam ruminansia, fermentasi usus dari bahan tanaman yang tertelan membebaskan fitol, penyusun klorofil, yang kemudian diubah menjadi asam fitat dan disimpan dalam lemak. Dalam hati hiu itu menghasilkan pristane. Patologi pada manusia. Penyakit Refsum, kelainan resesif autosomal yang diakibatkan oleh akumulasi sejumlah besar asam fitat dalam jaringan, sering kali mewarnai polineuropati perifer, ataksia serebelum, retinitis pigmentosa, anosmia, dan gangguan pendengaran. Meskipun manusia tidak dapat memperoleh asam fitat dari klorofil, mereka dapat mengubah phytol bebas menjadi asam fitat. Dengan demikian, pasien dengan penyakit Refsum harus membatasi asupan asam fitat dan phytol bebas. Jumlah phytol bebas dalam berbagai produk makanan telah dilaporkan. Peran di alam: Serangga, seperti kutu kutu sumac, dilaporkan menggunakan fitol dan metabolitnya (misalnya asam fitat) sebagai penghambat kimia terhadap predasi. Senyawa ini berasal dari tanaman inang. Bukti tidak langsung telah diberikan bahwa, berbeda dengan manusia, beragam primata non-manusia dapat menghasilkan sejumlah phytol yang signifikan dari fermentasi hindgut bahan tanaman.

Modulator transkripsi: Phytol dan / atau metabolitnya telah dilaporkan untuk mengikat dan / atau mengaktifkan faktor transkripsi PPAR-alpha [10] dan reseptor retinoid X (RXR). [11] Asam metabolit phytanic dan asam pristanat adalah ligan alami. Pada tikus phytol oral menginduksi proliferasi peroksisom yang besar di beberapa organ. Biomarker geokimia: Fitol kemungkinan adalah senyawa isoprenoid asiklik paling melimpah yang ada di biosfer dan produk degradasinya telah digunakan sebagai pelacak biogeokimia di lingkungan perairan. Aplikasi komersial: Phytol digunakan dalam industri wewangian dan digunakan dalam kosmetik, shampo, sabun toilet, pembersih rumah tangga, dan deterjen. Penggunaannya di seluruh dunia diperkirakan sekitar 0,1-1,0 metrik ton per tahun (Wikipedia, 2017). 
Phytol, senyawa organik yang digunakan dalam pembuatan vitamin E dan K1 sintetis. Phytol pertama kali diperoleh dengan hidrolisis (dekomposisi oleh air) dari klorofil pada tahun 1909 oleh ahli kimia Jerman Richard Wilstätter. Strukturnya ditentukan pada tahun 1928 oleh ahli kimia Jerman F.G. Fischer. Fitol dapat diperoleh dalam proses pemisahan klorofil dari alfalfa. Konversi phytol ke $\alpha$-tocopherol, vitamin E yang paling manjur yang penting untuk reproduksi tikus, dilaporkan dari tiga laboratorium pada tahun 1938 dan telah diaplikasikan dalam pembuatan komersial. Sintesis vitamin K1 dari phytol dikembangkan pada tahun 1939. (Encyclopya Britania, 2017).

Asam stearat adalah asam lemak rantai panjang jenuh dengan tulang punggung 18-karbon. Asam stearat ditemukan di berbagai lemak hewan dan tumbuhan, dan merupakan komponen utama mentega kakao dan shea-butter. Asam stearat, juga disebut asam octadecanoat, adalah salah satu jenis asam lemak jenuh penting yang berasal dari banyak lemak dan minyak hewani dan nabati. Ini adalah padatan lilin, dan rumus kimianya adalah $\mathrm{CH} 3(\mathrm{CH} 2) 16 \mathrm{COOH}$. Namanya berasal dari kata Yunani stear, yang berarti tallow. Nama IUPACnya adalah asam oktadekanoat. Asam stearat mempunyai bioaktifitas sebagai senyawa antikanker. Aktivitas antiviral dan antiinflamasi yang dilaporkan, formulasi krim yang mengandung n-docosanol (docosanol) atau asam stearat diuji untuk efek pada luka bakar yang diinduksi secara kimia pada tikus, secara substansial dan reprodusibel mengurangi tingkat keparahan dan perkembangan lesi kulit. (NCBI, 2017).

Total Flavonoid Ekuivalen Quercetin pada teh bayam merah antara pengujian pertama dan kedua terjadi penurunan hampir setengahnya. Penyimpanan menyebabkan kadar flavonoid ekuivalen quercetin menurun dari 0,98 menjadi $0,435 \%$ b/b. Quercetin adalah bioflavonoid. Jika karotenoid adalah pewarna alami, menciptakan banyak merah, oranye, kuning, dan warna hijau tua dalam buah dan sayuran, maka flavonoid bisa dianggap sebagai lapisan yang hidup dalam bermacam-macam jenis. Flavonoid adalah pigmen tumbuhan, memberi warna yang lebih hidup dan cemerlang di alam, termasuk sebagian besar warna hijau biru, ungu, dan hijau ditemukan di bunga, daun, buah, dan sayuran. Selain itu, sebagian besar kuning, oranye, dan merah yang bukan karotenoid milik keluarga flavonoid. Perbedaan lain adalah karotenoid larut dalam lipid. sedangkan flavonoid adalah terutama yang larut dalam air. Flavonoid mewakili keluarga besar phytonutrisi (tanaman nutrisi).

Lebih dari 4.000 flavonoid unik telah ada diidentifikasi sejauh ini - dan jumlahnya terus bertambah! Struktur kimia flavonoid adalah bagian dari keluarga yang lebih luas senyawa yang dikenal sebagai polifenol. Dalam makanan kita, flavonoid ditemukan terutama pada buah dan sayuran. Sejumlah besar flavonoid juga ditemukan di teh dan anggur. Buah jeruk dan buah beri sangat tinggi flavonoid. Pada tumbuhan, flavonoid tampak berperan sebagai tabir surya alami, melindungi dari kerusakan ultraviolet. Pada orang, Flavonoid tampak mengganggu kompleks dan multiple, proses yang mengarah pada penyakit kronis seperti kanker, penyakit jantung, dan penyakit degeneratif lainnya yang terkait dengan penuaan. Salah satu fungsi utama flavonoid diet adalah bertindak sebagai pelindung antioksidan dari daerah berair di dalam dan sekitar sel dan cairan tubuh seperti darah (GND, Product 4.06).

Flavonoid telah terbukti memiliki berbagai aktivitas biologis dan farmakologis dalam penelitian in vitro. Contohnya termasuk anti alergi, antiinflamasi, antioksidan, antibakteri, antijamur, dan antivirus, anti kanker, dan aktivitas anti-diare. Flavonoid juga telah terbukti menghambat nzim topoisomerase dan untuk menginduksi mutasi DNA pada gen leukemia campuran-linier (MLL) pada penelitian in vitro. Namun, dalam sebagian besar kasus di atas tidak ada tindak lanjut penelitian in vivo atau klinis yang telah dilakukan, membuat tidak mungkin untuk mengatakan apakah aktivitas ini memiliki efek menguntungkan atau merugikan pada kesehatan manusia. Aktivitas biologis dan farmakologis yang telah diteliti secara lebih mendalam dijelaskan di bawah ini. Studi klinis yang menyelidiki hubungan antara konsumsi flavonoid dan pencegahan / pengembangan kanker bertentangan untuk sebagian besar jenis kanker, mungkin karena sebagian besar penelitian bersifat retrospektif dan menggunakan ukuran sampel yang kecil. Dua pengecualian yang jelas adalah karsinoma gaster dan kanker yang berhubungan dengan merokok. Asupan flavonoid diet dikaitkan dengan risiko karsinoma gaster yang berkurang pada wanita, dan mengurangi risiko kanker saluran pernapasan pada perokok (Wikipedia, 2017).

Begitu juga dengan kadar total fenol ekuivalen asam gallat pada teh bayam merah segar (yang baru dibuat) dari $4,11 \%$ b/b turun setelah disimpan selama 2 bulan menjadi $1,78 \%$ b/b. Namun pada kadar sari larut air terjadi sebaliknya, yaitu peningkatan kadar dengan adanya proses penyimpanan (dari 15,18 menjadi 18,41\% b/b).Senyawa fenolik disintesis dalam industri; Mereka juga diproduksi oleh tanaman dan mikroorganisme, 
dengan variasi antara dan di dalam spesies. Meskipun mirip dengan alkohol, fenol memiliki sifat unik dan tidak diklasifikasikan sebagai alkohol (karena gugus hidroksil tidak terikat pada atom karbon jenuh). Mereka memiliki keasaman yang lebih tinggi karena kopling ketat cincin aromatik dengan oksigen dan ikatan yang relatif longgar antara oksigen dan hidrogen. Keasaman gugus hidroksil dalam fenol umumnya antara antara alkohol alifatik dan asam karboksilat (pKa mereka biasanya antara 10 dan 12). Kehilangan kation hidrogen $(\mathrm{H}+)$ dari gugus hidroksil fenol membentuk ion fenolat negatif atau ion fenoksida yang sesuai, dan garamnya sesuai disebut fenolat atau fenoksi, walaupun istilah ariloksin lebih disukai menurut Buku Emas IUPAC.

Fenol dapat memiliki dua atau lebih gugus hidroksi yang terikat pada cincin aromatik (s) dalam molekul yang sama. Contoh paling sederhana adalah tiga benzenadiol, masing-masing memiliki dua gugus hidroksi pada cincin benzen. Organisme yang mensintesis senyawa fenolik melakukannya sebagai respons terhadap tekanan ekologis seperti serangan patogen dan serangga, radiasi UV dan melukai. [7] Karena mereka hadir dalam makanan yang dikonsumsi dalam makanan manusia dan pada tanaman yang digunakan dalam pengobatan tradisional beberapa budaya, peran mereka dalam kesehatan dan penyakit manusia adalah subjek penelitian. Beberapa fenol adalah kuman dan digunakan dalam merumuskan desinfektan. Yang lainnya memiliki aktivitas mengganggu estrogenik atau endokrin (Wikipedia, 2017).

Sumber utama fenol alami dalam nutrisi manusia meliputi buah beri, teh, bir, minyak zaitun, coklat atau kakao, kopi, buah delima, popcorn, yerba maté, buah dan minuman berbasis buah (termasuk sari buah anggur dan cuka) dan sayuran. Herbal dan rempah-rempah, kacang-kacangan (kenari, kacang tanah) dan alga juga berpotensi signifikan untuk memasok fenol alami tertentu. Fenol alami juga dapat ditemukan pada matriks lemak seperti minyak zaitun. Minyak zaitun yang tidak disaring memiliki kadar fenol yang lebih tinggi, atau fenol polar yang membentuk kompleks fenol-protein kompleks. Senyawa fenolik, bila digunakan dalam minuman, seperti jus prune, telah terbukti membantu komponen warna dan sensorik, seperti mengurangi kepahitan. Beberapa pendukung klaim pertanian organik bahwa kentang organik, jeruk, dan sayuran daun tumbuh memiliki lebih banyak senyawa fenolik dan ini dapat memberikan perlindungan antioksidan terhadap penyakit jantung dan kanker. Namun, bukti tentang perbedaan substansial antara makanan organik dan makanan konvensional tidak cukup untuk membuat klaim bahwa makanan organik lebih aman atau lebih sehat daripada makanan konvensional (Wikipedia, 2017).

Penilaian efek antioksidan. Pengukuran in vitro. Tes lainnya mengukur kapasitas antioksidan dari fraksi. Beberapa menggunakan kation radikal 2,2'-azino-bis (3-ethylbenzothiazoline-6-sulphonic acid) (ABTS), yang reaktif terhadap kebanyakan antioksidan termasuk fenolat, tiol dan vitamin C. Selama reaksi ini, kation radikal ABTS biru diubah kembali ke bentuk netralnya yang tidak berwarna. Reaksi dapat dipantau secara spektrofotometri. Pengujian ini sering disebut sebagai tes kapasitas antioksidan setara Trolox (TEAC). Reaktivitas berbagai antioksidan yang diuji dibandingkan dengan Trolox, yang merupakan analog vitamin E.

Uji kapasitas antioksidan lainnya yang menggunakan Trolox sebagai standar meliputi dishenylpicrylhydrazyl (DPPH), kapasitas penyerapan radikal oksigen (ORAC), kemampuan pengurangan besi dari uji plasma (FRAP) atau penghambatan oksidasi lipoprotein densitas rendah in vitro manusia. Uji aktivitas antioksidan seluler (CAA) juga ada. Dichlorofluorescin adalah probe yang terjebak dalam sel dan mudah teroksidasi menjadi fluorescent diklorofluorescein (DCF). Metode ini mengukur kemampuan senyawa untuk mencegah pembentukan DCF dengan 2,2'-Azobis (2-amidinopropane) dihydrochloride (ABAP) -menerapkan radikal peroksil pada sel hepatoparcinoma manusia HepG2. Metode lainnya meliputi butylated hydroxytoluene (BHT), butylated hydroxyanisole (BHA), metode Rancimat (penilaian rancidification of fat) (Wikipedia, 2017).

Model in vivo. Larva model animal Galleria mellonella, juga disebut waxworms, dapat digunakan untuk menguji efek antioksidan dari molekul individu yang menggunakan asam borat dalam makanan untuk menginduksi stres oksidatif. Kandungan malondialdehid, indikator stres oksidatif, dan aktivitas enzim antioksidan superoksida dismutase, katalase, glutathione S-transferase dan glutathione peroxidase dapat dipantau. Prophenoloxidase juga dapat dipulihkan dari serangga (Wikipedia, 2017).

\section{Kesimpulan}

Bayam merah yang digunakan dalam penelitian ini berasal dari famili Amaranthaceae dengan jenis Amaranthus tricolor L. Bayam merah dapat dibuat dalam kemasan teh yang mudah dibawa dan digunakan. Hasil maserasi teh bayam merah menggunakan ethanol absolut berupa pasta berwarna hijau diidentifikasi 
menggunakan GCMS menghasilkan senyawa utama antara lain asam palmitat, asam elaidin/asam oleat, phytol, asam stearat. Penetapan kadar bahan aktif berupa total fenol ekuivalen asam gallat dan kadar total flavonoid ekuivalen quercetin antara teh bayam merah yang disimpan terjadi penurunan sekitar setengah, namun meningkat pada kadar sari larut air. Uji toksisitas akut oral yang dilakukan pada kelompok tikus putih dari strain Wistar baik jantan maupun betina dinyatakan praktis tidak toksis.

\section{Referensi}

Akhda, Dewi K.N, 2009. Pengaruh dosis dan waktu aplikasi kompos Azolla sp. Terhadap pertumbuhan tanaman Bayam merah (Althemathera amoena Voss) Jurnal Agrivita 7(4): 36-39.

Ariami, P: Adiadnya, IB Punia; Diarti, MW. Potensi Teh Daun Bayam Merah (Amaranthus tricolor L) Terhadap Aktivitas Penghambatan Tahap Pembelahan Sel (anti mitosis) Sel Embrio Bulu Babi (Diedema antillarum). JAMBS Volume 2 Nomor 2, September 2015.

Astawan, Made.,2004. Khasiat Makanan Mentah. Jakarta: Gramedia.

Bandini., Y. dan Azis, N. 2004. Bayam. Jakarta: Penerbit Penebar Swadaya.

Batra P.,Sharma AK. 2013. Anti-cancer potential of flavonoids: recent trends and future perpectives. Departement of Biotecnhology, MMEC.

Blagosklonny MV. 2001. Treatment With Inhibitors Of Caspases, That Are Substrates Of Drug Transporters, Selectively Permits Chemotherapy-Induced Apoptosis In Multidrug-Resistant Cell But Protect Normal Cells. Leukemia 15:936-941.

Batra P.,Sharma AK.,2013. Anti-cancer potential of flavonoids: recent trends and future perpectives. Departement of Biotecnhology, MMEC.

Dalimartha, 2004. Deteksi Dini Kanker dan Simplisia Anti Kanker. Jakarta: Penebar Swadaya.

Dalimartha.,2000. Atlas Tumbuhan Obat Indonesia. Jakarta: PT. Pustaka Pembangunan Swadaya Nusantara.

Di Pietro A, Conseil G, Perez-Victoria JM, Dayan G, Baubichon-Cortaya H, Trompuera D, dkk. Modulation by Flavonoid of cell multidrug resistance mediated by P-glycoprotein and related ABC transporters. Cell Mol Life Sci 59:307-322.

Guyton AC., 1995. Fisiologi Manusia dan Mekanisme Penyakit. Jakarta: Penerbit buku Kedokteran EGC.

Herani dan M Rahardjo. 2005. Tanaman berkhasiat antioksidan. Jurnal Dinamika Pertanian 19 (3):98-99

Hastak K, Gupta S, Ahmad N, Agarwal MK, Argarwal ML, Mukhtar H.,2003. Role of p53 and NF-kappaB in epigallocatechin-3-gallate induced apoptosis of LNCap cells. Oncogene 22:4851-4859.

Hodek P, Trefil P, Stiborova M.,2002. Flavonoids: potent and versatile biologically active compounds interacting with cyto-chromes P450. Chem Biol Interact 139(1):1-21.

Houghton, J.D; Hendry, G.A.F. (1995). Natural food colorants. Springer. ISBN 978-0-7514-0231-5.Page.5359 dalam Wikipedia https://id.wikipedia.org/wiki/Antosianin

Jong WD., 2005. Kanker, Apakah Itu? Pengobatan, Harapan Hidup, dan Dukungan Keluarga. Jakarta: Arcan.

Peraturan Kepala BPOM R I, Nomor 7 Tahun 2014. Pedoman Uji Toksisitas Nonklinik secara invivo.

Katzung B.G.,1989. Farmakologi Dasar Dan Klinik. hal 808. Jakarta: EGC.

Leslie PG., Hiatt JL., Strum JM., 2012. Biologi Sel dan Histologi Edisi Keenam. Jakarta: Binarupa Aksara. 
Li YC.,2011. Antioxidant Activity Of Flavonoids From Sweet Potato Vines In Vitro. Adv Mater Res 236238:2634-2638.

Mardiawan D., 2006. Pengaruh Pemberian Ekstrak Tapak Dara (Catharanthus roseus) dan Temulawak (Curcuma xanthorhiza) Terhadap Ukuran Tumor dan Gambaran Hispatologik Paru dan Kelenjar Limfe Aksilia Mencit C3H yang Telah Diinokulasi Sel Adenocarcinoma Mammae. Universitas Diponegoro Semarang.

Meiyanto E., Susilowati S., Taminatun S., Murwanti R., Sugiyanto. Efek Kemopreventif Ekstrak Gynura procumbent (Lour) Merr pada Karsinogenesis Kanker Payudara Tikus. MFI, 2007, 18(3):154-161.

Rumimper EA, Posangi J, \& Wuisan J. Uji efek perasan daun bayam merah (Amaranthus tricolor) terhadap kadar hemoglobin pada tikus putih Wistar (Rattus norvegicus). Jurnal e-Biomedik(eBM). Volume 2, Nomor 2. Juli 2014.

Trihardjana, 2007. Kajian Potensi Diuretika dari Beberapa Jenis Tanaman di Sekitar Rumah. . Jurdik Biologi FMIPA UNY

http://staff.uny.ac.id/sites/default/files/131782835/deuritik\%20tanaman\%20sekitar\%20rumah.pdf. Aug 25, 2007

Shirli EO, 2005. Buku Saku: Keperawatan Onkologi. Jakarta, EGC.

Sukardja.,2000. Onkologi Klinik. Surabaya: UAP.

Sunarjono., 2006. Pengaruh Penggunaan Input Produksi Nyata Terhadap Jumlah Produksi Usaha Tani Bayam. Skripsi Universitas Sumut.

Tim Cancer Helps. 2010. Stop Kanker: “Kanker bukan Vonis Mati”. Jakarta: Agromedia Pustaka.

Wikipedia, 2017. Asam palmitat, Phytol, Asam elaidin, Asam stearate. 